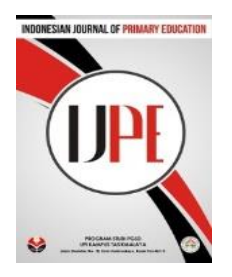

Vol 1 No 1 (2017) 1-11

Indonesian Journal of Primary Education

\title{
Hasil Belajar Materi Gaya dan Gerak melalui Penerapan Permainan Senapan Gaya
}

\author{
Tri Handayani \\ SDN 10 Curup Timur - Rejang Lebong Provinsi Bengkulu \\ trihandayanitambrin@gmail.com
}

Diterima 10 Maret 2017; Direview 15 April 2017; Diterima 5 Juni 2017

Diterbitkan online 17 Juni 2017

\begin{abstract}
Abstrak
Peningkatan Hasil Belajar Materi Gaya dan Gerak Melalui Penerapan Permainan Senapan gaya merupakan sebuah Penelitian Tindakan Kelas (PTK). Tujuan Penelitian ini adalah untuk mengetahui peningkatan hasil belajar siswa setelah menggunakan permainan Senapan Gaya pada siswa kelas VI SDN 10 Curup Timur. Hasil penelitian ini menunjukan bahwa penerapan permainan Senapan Gaya dapat meningkatkan hasil belajar siswa kelas VI pada pelajaran IPA materi gaya dan gerak. Permainan senapan gaya digunakan sebagai media pembelajaran bagi siswa kelas VI SDN 10 Curup Timur karena dapat meningkatkan pemahaman terhadap materi gaya dan gerak serta memberikan suasana belajar yang rileks dan menyenangkan. Selain itu Hasil belajar meningkat dengan sangat signifikan, dimana ketuntasan hasil belajar individu meningkat dari 17 orang pada siklus I menjadi 27 orang pada siklus II. Rata-rata kelas meningkat dari 69,44 pada siklus I menjadi 82,00 pada siklus II.
\end{abstract}

Kata kunci: Materi Gaya dan Gerak, Permainan Senapan Gaya

\section{PENDAHULUAN}

Pada hakikatnya Ilmu Pengetahuan Alam (IPA) didefinisikan sebagai kumpulan pengetahuan yang tersusun secara terbimbing. Selain itu IPA juga merupakan ilmu yang membahas tentang fakta serta gejala alam. Fakta dan gejala alam tersebut tidak hanya verbal tetapi juga faktual. Hakikat IPA sebagai proses diwujudkan dengan melaksanakan pembelajaran yang melatih ketrampilan proses bagaimana cara produk sains ditemukan.

Asy'ari, Muslichah (2006,hlm.22) menyatakan bahwa ketrampilan proses yang perlu dilatih meliputi ketrampilan proses dasar misalnya mengamati, mengukur, mengklasifikasikan, mengkomunikasikan, mengenal hubungan ruang dan waktu, serta ketrampilan proses terintegrasi misalnya merancang dan melakukan eksperimen yang menyusun hipotesis, menentukan variabel, menyusun definisi operasion`al, menafsirkan data, menganalisis, dan mensintesis data. Sikap tersebut dapat terbentuk apabila siswa langsung melakukan percobaan dengan cara yang menyenangkan, tidak hanya dari pembelajaran yang monoton saja.

Dari berbagai macam materi IPA yang diajarkan di kelas VI, salah satu materi yang paling banyak diminati siswa adalah materi gaya dan gerak. Gaya dan gerak berkaitan erat dalam kehidupan sehari - hari. Tanpa kita sadari, kita banyak melakukan gerak dan mengeluarkan gaya. Menurut Moch, Azam (2009, hlm.101) gaya adalah dorongan atau tarikan yang diberikan pada suatu benda. Untuk melakukan suatu gaya, diperlukan 
tenaga. Gaya dan tenaga mempunyai arti yang tidak sama, namun keduanya saling berhubungan. Gaya tidak dapat dilihat, tetapi pengaruhnya dapat dirasakan. Tarikan dan dorongan yang dilakukan memerlukan tenaga, tenaga yang dikeluarkan dapat dilihat dengan gerak. Gerak adalah perpindahan posisi atau kedudukan suatu benda.

Aktivitas siswa dalam pembelajaran besar nilainya bagi pembelajaran itu sendiri. Kondisi pembelajaran yang menyenangkan dapat memungkinkan siswa untuk mengembangkan potensi dalam dirinya sehingga mendapat pembelajaran yang berharga baik dari segi pengetahuan, nilai maupun psikomotorik. Aktivitas yang dilakukan siswa dalam pembelajaran sangat berdampak pada hasil belajar.

Hasil belajar yang dicapai siswa menurut Sudjana(1990,hlm.56), melalui proses belajar mengajar yang optimal ditunjukkan dengan ciri-ciri sebagai berikut ; (1) Kepuasaan dan kebanggaan yang dapat menumbuhkan motivasi belajar intrinstik pada diri siswa. Siswa tidak mengeluh dengan prestasi yang rendah dan ia akan berjuang lebih keras untuk memperbaikinya atau setidaknya mempertahankan apa yang telah dicapai. (2) Hasil belajar yang dicapai bermakna bagi dirinya, seperti akan tahan lama diingat, membentuk prilaku, bermanfaat untuk mempelajari aspek lain, kemauan dan kemampuan untuk belajar sendiri dan mengembangkan kreativitasnya. (3) Hasil belajar yang diperoleh siswa secara menyeluruh( komperhensif), yakni mencakup ranah kognitif, pengetahuan atau wawasan, ranah efektif (sikap) dan ranah psikomotorik, keterampilan atau prilaku. (4) Kemampuan siswa mengontrol atau menilai dan mengendalikan diri terutama dalam menilai hasil yang dicapainya maupun menilai dan mengendalikan proses usaha belajarnya.

Salah satu usaha yang dilakukan untuk meningkatkan aktivitas dan hasil belajar siswa materi Gaya dan Gerak yaitu dengan menggunakan Senapan gaya. Istilah Senapan gaya diambil dalam kamus bahasa indonesia yaitu senjata api berlaras panjang, yang tidak memakai mesiu, ditembakkan dengan kekuatan tekanan udara. Permainan senapan gaya ini biasanya digunakan anak-anak sebagai pengganti pistol-pistolan . Permainan senapan gaya adalah permainan yang mengunakan bahan pipa bekas sebagai pengganti pistol pistolan dan balon sebagai pengganti pelatuknya. Peluru yang digunakanpun terbuat dari bubur kertas yang dikeringkan sehingga tidak berbahaya bagi siswa. Dalam permainan Senapan gaya siswa dibagi dalam beberapa kelompok, sehingga masing masing kelompok nantinya akan melakukan tembakan sesuai dengan istrumen yang telah diberikan.

Dari berbagai macam materi IPA yang diajarkan di kelas VI, salah satu materi yang paling banyak diminati siswa adalah materi gaya dan gerak. Gaya dan gerak berkaitan erat dalam kehidupan sehari-hari. Tanpa kita 
sadari, kita banyak melakukan gerak dan mengeluarkan gaya.

Meskipun materi gaya dan gerak banyak diminati siswa, tetapi para siswa mengalami kesulitan dalam memahami materi tersebut. Kesulitan belajar. Kesulitan yang dialami siswa yaitu tidak memahami konsep yang sebenarnya mengenai gaya dan gerak.

Materi gaya dan gerak sebenarnya telah dipelajari dari kelas IV SD dan dilanjutkan lagi ke tingkat selanjutnya yaitu kelas $\mathrm{V}$ dan kelas VI, tetapi realita dilapangan pada saat siswa berada dikelas VI lebih dari $50 \%$ siswa belum memahami pengaruh gaya dan gerak benda bahkan ada siswa yang tidak tahu sama sekali apa itu gaya.

Permainan Senapan Gaya merupakan salah satu cara yang membuat siswa semangat dan termotivasi untuk belajar IPA khususnya materi gaya dan gerak. Beberapa penelitian tentang pembelajaran gaya dan gerak pernah dilaksanakan, Penelitian yang pertama oleh Zulaikha, Rahmawati (2011) berjudul, Meningkatkan Hasil Belajar IPA tentang Gaya dan Gerak Melalui Model Pembelajaran Toys dan Trick Siswa kelas V SDN Waleng Kecamatan GiriMarto Kabupaten Wonogiri Tahun Pelajaran 2010/2011. Hasil dari penelitian ini adalah (1) tahap perencanaan pembelajaran telah mampu meningkatkan pemahaman siswa dalam membedakan gaya dan gerak. (2) tahap penilaian telah mampu meningkatkan hasil belajar siswa. Kedua , penelitian oleh Kanti Sukowati (2014) yang berjudul Meningkatkan Hasil Belajar Mata
Pelajaran IPA materi Gaya Dan Gerak Menggunakan Metode Demonstrasi Pada Siswa Kelas VIA SDN Darungan 01 Kecamatan Tanggul Kabupaten Jember. Hasil penelitian ini adalah (1) setelah menggunakan metode demonstrasi aktivitas siwa meningkat di setiap siklus. (2) berdasarkan hasil persentase hasil belajar siswa, hasil belajar yang dikatakan tuntas mengalami peningkatan drastis.

Berdasarkan pertimbangan tersebut, peneliti berusaha memberikan alternatif strategi pembelajaran yang kreatif dengan memanfaatkan sumber daya alam yang ada disekitar serta permainan keseharian anakanak yang dapat dibuat sendiri. Selain itu, permainan tersebut dapat dihubungkan dengan materi gaya dan gerak sehingga dapat dikatakan belajar sambil bermain. Belajar sambil bermain merupakan salah satu strategi belajar yg efektif. Belajar dikatakan efektif menurut Aunnurrahman (2009,hlm.34) menyatakan bahwa "pembelajaran yang efektif ditandai dengan terjadinya proses belajar dalam diri siswa". Seseorang dikatakan telah mengalami proses belajar apabila di dalam dirinya telah terjadi perubahan, dari tidak tahu menjadi tahu, dari tidak mengerti menjadi mengerti.

Melalui belajar sambil bermain siswa menjadi lebih senang mengikuti pelajaran serta tidak mudah bosan. Tidak hanya itu, siswa juga bisa memperoleh ketrampilan tambahan diluar materi yang diajarkan. Seorang siswa bisa belajar melalui proses permainan, dengan 
permainan para siswa bisa belajar konsep dan ide baru dalam belajar. Siswa bisa melihat materi yang diajarkan dari sesuatu yang belum mereka ketahui sebelumnya. Permainan juga bisa menjadi perantara untuk mengikutsertakan murid dalam proses belajar mengajar . Pelajaran IPA memerlukan keterampilan baik keterampilan berpikir maupun keterampilan tangan (motorik). Melalui permainan guru dapat mengajak siswa untuk memahami hubungan antara gaya dan gerak. Sebuah permainan bisa menjadi salah satu faktor penguat memori.

Salah satu penelitian yang pernah dilakukan mengenai permainan dapat menguatkan memori yaitu oleh Maulana Priyahardanta (2016) yang berjudul Peningkatan Keaktifan Siswa Dengan Menerapkan Model Permainan Papan Memori Dalam Pembelajaran IPS Kelas V di Sd Negeri Suryodiningrat 2 Yogyakarta Tahun ajaran 2015/2016. Hasil pengamatan penulis tepatnya di SDN 10 Curup Timur diperoleh data bahwa banyak siswa yang tidak tahu sama sekali apa itu gaya dan gerak lebih dari $50 \%$ dari 27 siswa. Kebanyakan siswa hanya diam dan mendengarkan saja materi yang disampaikan guru, dan terlihat sama sekali tidak bersemangat dan kurang merespon materi yang diberikan. Siswa banyak kurang memahami tentang gaya dan hubungannya dengan gerak, apalagi jika dikaitkan dengan aplikasi dalam kehidupan sehari-harinya. Dengan memperhatikan kenyataan tersebut penulis tertarik melakukan penelitian dengan judul " Peningkatan Hasil Belajar Materi Gaya dan Gerak Melalui Penerapan Permainan Senapan Gaya Siswa Kelas VI SDN 116 Rejang Lebong”.

Adapun rumusan masalah di dalam penelitian tindakan kelas ini adalah bagaimana penerapan permainan senapan gaya kelas VI SDN 10 Curup Timur dapat meningkatkan hasil belajar siswa. Tujuan penelitian ini adalah untuk mengetahui peningkatan hasil belajar siswa setelah penerapan permainan senapan gaya pada siswa kelas VI SDN 10 Curup Timur.

\section{METODE PENELITIAN}

Penelitian ini dilakukan dengan subjek siswa kelas VI SDN 10 Curup Timur sebanyak 27 siswa pada semester pertama tahun pelajaran 2015/2016. Masing-masing siswa memiliki karakter yang relatif sama di bidang akademik, tidak ada yang terlalu menonjol maupun sangat lemah. Penelitian ini dilaksanakan menggunkaan metode Penelitian Tindakan Kelas (PTK ) secara berkolaborasi dengan teman sejawat, guru di sekolah yang sama. Dilaksanakan selama 2 (dua) siklus, setiap siklusnya mengacu pada model R.Mc Tagart \& Kemmis,S (1998,hlm.142) dengan tahapan perencanaan, tindakan, pengamatan, serta refleksi untuk setiap siklus.

Perencanaan pada siklus I diawali dengan kegiatan persiapan mengadakan penelitian menyusun rumusan masalah, tujuan, dan membuat rencana tindakan, termasuk instrumen pembelajaran dan perangkat pembelajaran. Proses Perencanaan (Planning) 
Tindakan Siklus I dengan mempersiapkan buku pelajaran, perlengkapan dan bahan untuk membuat senapan gaya, menyiapkan lembar evaluasi, menentukan observer dan membagi siswa menjadi beberapa kelompok.Tindakan pengamatan dilakukan secara bersamaan. Tindakan oleh peneliti sedangkan pengamatan dilakukan oleh teman sejawat (kolaborasi).

Dalam pelaksanaan tindakan yang direalisasinya sebagai bentuk pembelajaran dilakukan sebagai berikut; (1) materi gaya dapat mempengaruhi gerak benda (2) materi gaya dapat mempengaruhi arah benda. Pengamatan dilakukan menggunakan alat bantu lembar observasi dan catatan lapangan. Aspek yang diamati antara lain kegiatan awal yang meliputi apersepsi, pemberian motivasi belajar, menjelaskan tujuan pembelajaran. Kegiatan inti diantaranya;(1) guru mengkondisikan siswa untuk berkelompok,(2) meminta salah seorang siswa untuk memperagakan cara pembuatan senapan gaya,(3) Guru mengadakan pembelajaran di luar kelas, (4) siswa merakit sendiri senapan gaya dan mulai melakukan permainan. (5) Setelah bermain siswa kembali ke kelas dan mempresentasikan hasil diskusi kelompoknya masing masing. Kegiatan akhir pembelajaran meliputi; (1) siswa dengan bimbingan guru menyimpulkan hasil pembelajaran, memberi kesempatan siswa untuk bertanya, (3) siswa mengerjakan tes akhir dan guru mengkondisikan untuk pelaksanaan evaluasi.

Kegiatan Refleksi siklus I dilakukan setelah proses pengolahan data, baik data yang diperoleh dari pengamatan maupun post test setiap siklusnya. Hasil refleksi ini dijadikan pedoman untuk penyusunan rancangan bagi pelaksanaan tindakan pada siklus berikutnya . Perencanaan pada siklus II berdasarkan refleksi siklus I yaitu memberikan motivasi dan pemahaman kepada kelompok untuk terampil dalam permainan senapan gaya, memberikan instrumen yang jelas kepada siswa dalam melakukan permainan senapan gaya, lebih intensif membimbing dan mengarahkan siswa serta memberi penguatan dan penghargaan.

Pada tahap tindakan dan pengamatan yang dilakukan antara lain kegiatan awal yang berisi apersepsi, pemberian motivasi belajar dan menjelaskan tujuan pembelajaran. Pada kegiatan inti guru mengkondisikan siswa menjadi berkelompok, guru memberikan instrumen sehingga pembelajaran menjadi terarah, guru mengarahkan ketua kelompok sebelum melakukan permainan senapan gaya, siswa membagi tugas kelompoknya, guru membimbing siswa dalam permainan senapan gaya, siswa berdiskusi dan melakukan permainan senapan gaya sesuai dengan instrumen yang diberikan guru, setelah permainan masing masing kelompok menyampaikan hasil yang telah diperoleh pada saat permainan. Guru memberikan apresiasi dan penguatan kepada kelompok terbaik dan siswa yang mendapat nilai tertinggi. Pada kegiatan penutup tindakan yang dilakukan yaitu siswa dengan bimbingan guru menyimpulkan hasil pembelajaran, 
mengerjakan tes akhir dan mendapatkan tindak lanjut berupa pekerjaan rumah.

\section{Data dan Teknik Pengumpulan Data}

Pengumpulan data pada penelitian ini dilakukan dengan teknik sebagai berikut ; 1) Observasi yang dilaksanakan untuk memperoleh data kualitatif yaitu aktivitas siswa dalam mengikuti Proses Belajar mengajar dengan bantuan instrumen (alat observasi). Terdapat 5 aspek yang diamati dalam pelaksanaan pembelajaran yaitu; (1) mendengarkan/memperhatikan penjelasan guru, (2) bersungguh-sungguh dalam permainan senapan gaya, (3) bekerjasama dengan teman, (4) bertanya kepada guru apabila membutuhkan informasi untuk pemecahan masalah.(5) menarik kesimpulan. 2) TES, yaitu ulangan yang dilakukan pada akhir setiap siklusnya, tes berbentuk essay.

Dalam penelitian ini, aspek yang dinilai terdiri dari empat aspek yaitu kemampuan membuat Senapan gaya, kemampuan menggunakan alat yang dibuat, kerjasama antar anggota kelompok, pemahaman siswa dalam mengisi lembar instrumen tentang gaya dan gerak. Masing masing aspek diberi skor maksimal. Adapun hasil data tes dalam penelitian ini dianalisis secara kuantitatif, dengan rumus dasar sebagai berikut;Mencari skor/nilai. Rumus yang digunakan untuk penelitian ini berdasarkan pendapat M.Ngalim Purwanto, (1986,hlm.143) yaitu S=R/N x 100.

Data yang terkumpul diolah, ditetapkan penskoran dan kriterianya. Berikut dideskripsikan penskoranya hasil belajar yaitu tiap item diberi skor 10 untuk soal yang dijawab benar oleh siswa. Nilai siswa dikatakan tuntas apabila memperoleh nilai diatas KKM. KKM yang digunakan dalam Tes tertulis ini yaitu 60 .

Aktivitas siswa dimaknai dengan skor pengamatan dan skor aktivitas tiap aspek. Dalam skor pengamatan, siswa mendapat skor 1 jika mendengarkan atau memperhatikan penjelasan guru. Mendapat skor 2 jika bersungguh-sungguh dalam permainan senapan gaya. Skor 3 jika bekerjasama dengan teman. skor 4 jika berani bertanya kepada guru apabila menemukan suatu masalah. Skor 5 apabila bisa menarik kesimpulan. Skor angka itu sendiri diartikan sebagai berikut; skor 5 baik sekali, skor 4 baik, skor 3 cukup, skor 2 kurang, skor 1 kurang sekali. Masing masing skor maksimal nilainya 0-20.

Untuk memperoleh data dalam penelitian ini dideskripsikan sebagai berikut:

Tabel 1. Interval Penskoran aktivitas Siswa

\section{HASIL PENELITIAN}

Data yang diperoleh dari pengamatan yang dilakukan oleh teman observer baik siklus 1 (satu) maupun siklus 2 (dua) dalam penelitian ini dituangkan dalam tabel 1 berikut:

Tabel 1

Data Hasil Pengamatan

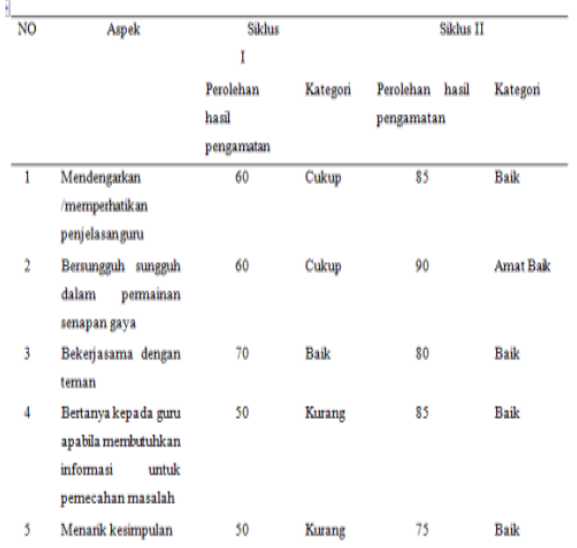


Aktivitas siswa menjelaskan secara klasikal skor siswa. Dari 5 aspek pengamatan hasil siklus I yaitu pada aspek no 1 siswa mendapat skor 60 untuk mendengarkan dan memperhatikan penjelasan guru sehingga termasuk dalam ketegori cukup, pada aspek no 2 siswa mendapat skor 60 dalam bersungguhsungguh melakukan permainan senapan gaya sehingga termasuk dalam kategori cukup. Pada aspek no 3 siswa mendapat skor 70 dalam bekerjasama dengan teman sehingga termasuk ke dalam kategori baik, pada aspek no 4 siswa mendapat skor 50 dalam bertanya kepada guru apabila membutuhkan informasi untuk pemecahan masalah sehingga termasuk dalam kategori kurang, pada aspek no 5 siswa mendapat skor 50 dalam kemapuan menarik kesimpulan sehingga termasuk kategori kurang.

Pada siklus II terjadi peningkatan pada aspek pengamatan, pada aspek no 1 siswa memperoleh skor 85 dalam mendengarkan dan memperhatikan penjelasan guru sehingga termasuk dalam ketegori baik, pada aspek no 2 siswa memperoleh skor 90 dalam bersungguh-sungguh melakukan permainan senapan gaya sehingga termasuk dalam kategori amat baik. Pada aspek no 3 siswa memperoleh skor 80 dalam bekerjasama dengan teman sehingga termasuk ke dalam kategori baik, pada aspek no 4 siswa mendapat skor 85 dalam bertanya kepada guru apabila membutuhkan informasi untuk pemecahan masalah sehingga termasuk dalam kategori baik, pada aspek no 5 siswa mendapat skor 75 dalam menarik kesimpulan sehingga termasuk kategori baik, dari 5 aspek terdapat satu aspek pengamatan yaitu bersungguh sungguh dalam permainan senapan gaya masuk dalam kategori amat baik dan keempat aspek lainnya masuk kedalam kategori baik.

\section{Tabel 2}

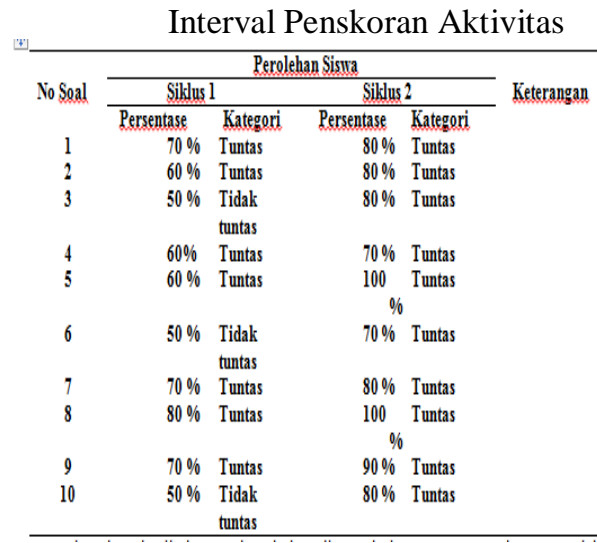

Berdasarkan hasil data pada tabel 2 diatas dari 10 nomor soal mengenai hasil belajar, soal nomor 1 pada siklus $170 \%$ siswa mencapai ketuntasan dan meningkat pada siklus ke 2 menjadi $80 \%$ sehingga termasuk dalam kategori tuntas. Soal nomor 2 pada siklus $1 \quad 60 \quad \% \quad$ siswa yang mencapai ketuntasan dan meningkat menjadi $80 \%$ pada siklus II sehingga termasuk dalam kategori tuntas. Soal nomor 3 pada siklus I hanya $50 \%$ siswa yang tuntas tetapi pada siklus ke 2 terjadi peningkatan $80 \%$ sehingga termasuk dalam kategori tuntas. Soal nomor 4 pada siklus I $60 \%$ siswa mencapai ketuntasan dan meningkat pada siklus II $70 \%$ sehingga termasuk dalam kategori tuntas.

Soal nomor 5 pada siklus I $60 \%$ siswa mencapai ketuntasan dan meningkat pada 
siklus II $100 \%$ sehingga termasuk dalam kategori tuntas. Soal nomor 6 pada siklus I hanya 50\% siswa yang mencapai ketuntasan dan meningkat pada siklus II $70 \%$ sehingga masuk dalam kategori tuntas. Soal nomor 7 pada siklus I 70\% siswa mencapai ketuntasan dan meningkat menjadi $80 \%$ pada siklus II sehingga masuk dalam kategori tuntas. Soal nomor 8 pada siklus I $60 \%$ siswa mencapai ketuntasan dan meningkat menjadi $80 \%$ pada siklus II sehingga masuk dalam kategori tuntas. Soal nomor $970 \%$ siswa mencapai ketuntasan dan meningkat menjadi $90 \%$ pada siklus II sehingga masuk dalam kategori tuntas. Soal nomor 10 hanya 50\% siswa yang tuntas tetapi pada siklus ke 2 meningkat menjadi $80 \%$ sehingga masuk dalam kategori tuntas.

Refleksi dilakukan berdasarkan hasil pembahasan siklus I. Diperoleh beberapa aspek yang sudah sesuai dengan target, siswa sudah menunjukkan ketertarikan, semangat, antusias dalam mengikuti pembelajaran yang dilakukan dengan menggunakan permainan senapan gaya . Namun, masih juga terdapat kelemahan, terutama pada pemecahan masalah . Hal ini berdampak pada hasil pembelajaran terkait pemecahan masalah yang ditampilkan pada soal no 3 dan 6 mengenai pengaruh gaya terhadap gerak benda dan no 10 mengenai jenis jenis gaya yang dapat mempengaruhi gerak benda. Pada aspek pengamatanpun masih terdapat aspek yang masuk kedalam kategori kurang yaitu aspek bertanya kepada guru apabila membutuhkan informasi untuk pemecahan masalah dan aspek menarik kesimpulan yang masing masing aspek hanya memperoleh skor 50.

Untuk memperbaiki kesalahan dan mempertahankan keberhasilan yang sudah dicapai pada siklus pertama, maka pada siklus kedua dapat dibuat perencanaan sebagai berikut; (1) Memberikan motivasi dan pemahaman kepada kelompok untuk lebih kreatif dan terampil dalam menggunakan media pembelajaran serta aktif dalam permainan Senapan Gaya.(2) Memberikan instrumen yang jelas kepada siswa mengenai apa yang harus dilakukan dalam permainan Senapan Gaya. (3) Lebih intensif membimbing dan mengarahkan siswa dalam menggunakan media pembelajaran yang telah disiapkan. (3) Memberi penguatan atau penghargaan. Data kuantitatif yang disebut sebagai hasil belajar diperoleh dari setiap siklusnya dituangkan dalam tabel 3 berikut:

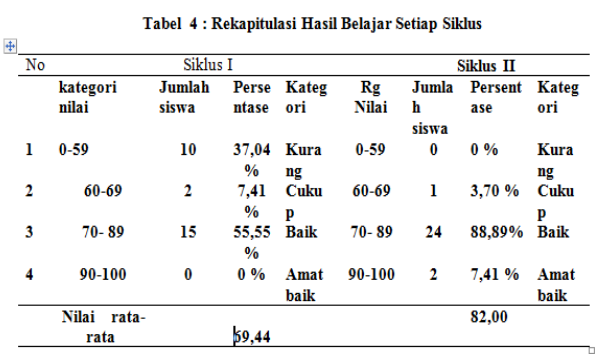

Berdasarkan tabel 3 di atas hasil belajar gaya dan gerak siswa kelas VI SDN 10 Curup Timur tahun ajaran 2015/2016 setelah diberikan tindakan I dapat disimpulkan bahwa secara umum siswa sudah memahami materi gaya dan gerak hal ini terlihat dari perolehan nilai persiklus, siswa yang mendapat kategori nilai 0-59 pada siklus I 
kategori kurang $37,04 \%$ dan $0 \%$ pada siklus II, ini membuktikan bahwa terdapat peningkatan keberhasilan.

Kategori nilai 60-69 pada siklus I kategori cukup $7,41 \%$ dan $3,70 \%$ pada siklus II, ini membuktikan peningkatan keberhasilan pembelajaran yang tadinya 2 orang yang mendapat nilai cukup menjadi 1 orang. Kategori nilai 70-89 pada siklus I kategori baik 55,55 \% dan $88,89 \%$ pada siklus II, ini membuktikan terjadi peningkatan yang baik. Kategori nilai 90-100 pada siklus I kategori amat baik $0 \%$ dan $7,41 \%$ pada siklus II, ini membuktikan terjadi peningkatan yang baik. Dari data siklus I dan II bisa dikatakan pembelajaran menggunakan permainan senapan gaya berhasil meningkatkan hasil belajar siswa, terbukti juga dengan meningkatnya nilai rata-rata kelas yang pada siklus I 69,44 menjadi 82,00 pada siklus II.

\section{PEMBAHASAN}

Berdasarkan data yang diperoleh dalam tabel 2,3 dan 4 dari siklus I dan 2 untuk meningkatkan hasil belajar melalui bermain Senapan Gaya dalam pembelajaran IPA materi gaya dan gerak pada siswa kelas VI SDN 10 Curup Timur membuktikan teori Sudjana tentang hasil belajar yang berhubungan dengan kemampuan yang dimiliki siswa setelah ia menerima pengalaman belajarnya. Terbukti dari hasil pembelajaran ketuntasan hasil belajar secara individu meningkat dari 17 orang pada siklus I dan meningkat lagi menjadi 27 orang pada siklus II. Rata-rata kelas meningkat dari 67,26 sebelum siklus I meningkat menjadi 69,44 pada siklus II dan meningkat lagi menjadi 82,00 pada siklus II.

Peningkatan hasil belajar tersebut disebabkan karena siswa makin terlatih dan semangat dalam mengkaji materi yang diberikan. Aktivitas siswa meningkat, dari 5 aspek yang diamati terjadi peningkatan $\begin{array}{lll}\text { disetiap } & \text { siklusnya. } & \text { Aspek }\end{array}$ mendengarkan/memperhatikan guru meningkat dari skor 60 menjadi 85. Aspek bersungguh-sungguh dalam permainan senapan gaya juga meningkat dari skor 60 menjadi 90. Aspek bekerjasama dengan teman dari skor 70 menjadi 80. Aspek bertanya kepada guru apabila membutuhkan informasi untuk pemecahan masalah meningkat dari skor 50 menjadi 85. Aspek menarik kesimpulan dari skor 50 meningkat menjadi 75 .

Refleksi, pada tahap refleksi ini ada beberapa hal yang dilakukan guru, dari aspek akademik atau hasil belajar ada beberapa hal yang harus diperbaiki pada siklus I yaitu lebih intensif lagi membimbing dan mengarahkan siswa dalam proses pembelajaran sehingga hasil beajar pada siklus II meningkat dan bisa dikatakan berhasil. Sedangkan dari aspek pengamatan ada 2 aspek yang harus diperbaiki, dari siklus I dan II rekomendasinya terbatas bagaimana cara meningkatkan kepercayaan diri siswa dan keberanian siswa dalam bertanya untuk pemecahan masalah dan menarik kesimpulan. 


\section{SIMPULAN}

Berdasarkan hasil Pembelajaran materi gaya dan gerak dengan penerapan permainan Senapan Gaya dapat meningkatkan aktivitas dan hasil belajar belajar siswa kelas VI SDN 10 Curup Timur. Hal ini dapat dilihat dari peningkatan setiap siklus, dari siklus I dan siklus II. Pada awal tes siswa yang tidak tuntas yaitu 70,37 \% atau sebanyak 19 orang. Pada siklus I siswa yang tidak tuntas menjadi 37,07 $\%$ atau 10 orang. Dan pada siklus ke II semua siswa tuntas mencapai KKM.

\section{SARAN}

Berdasarkan dari pengalaman yang diperoleh peneliti, penerapan permainan Senapan Gaya bisa dijadikan sebagai salah satu alternatif strategi pembelajaran dalam menyelesaikan masalah pada materi gaya dan gerak kelas VI SDN 10 Curup Timur.

Oleh karena , pada kesempatan ini saran yang dapat disampaikan adalah; (1)Bagi guru kelas, hasil penelitian ini dapat dijadikan masukan untuk meningkatkan proses pembelajaran materi gaya dan gerak.(2) Bagi peneliti lain, hasil penelitian ini dapat dijadikan acuan dalam melakukan penelitian sejenis.(3) Bagi kepala sekolah, hasil penelitian ini dapat dijadikan acuan dalam membuat kebijakan tentang peningkatan kualitas pembelajaran disekolah.(4) Bagi siswa, penelitian ini bermanfaat untuk meningkatkan keaktifan dalam proses pembelajaran, karena suasana pembelajaran menyenangkan, dan semua siswa terlibat aktif dalam pembelajaran berdasarkan masalah, sehingga pada akhirnya akan meningkatkan keterampilan belajar siswa.

\section{REFERENSI}

Asyari,Muslichah.2006."Penerapan sains teknologi Masyarakat dalaPembelajaran sains Di SD”. Tersedia online di: www.eprints.ums.ac.id (diakses di Rejang Lebong, Indonesia: 20 Desember 2015).

Aunnurrahman. 2009. Belajar dan pembelajaran. Bandung : Alfabeta

Azam,Much.2009. Akrab Dengan Dunia IPA. Bandung: PT.Tiga serangkai: Pustaka mandiri

Purwanto, M.Ngalim. 1986, "Prinsip-prinsip dan teknik Evaluasi Pengajaran". Tersedia online di: www.library.um.ac.id.com. (diakses di Rejang Lebong, Indonesia: 3 Januari 2016

Priyahardanta,Maulana.2016. "Peningkatan keaktifan siswa dengan menerapkan modelpermainan papan memori dalam pembelajaran IPS kelas $V \quad d i$ SDNegeriSuryodiningrat 2 Yogyakarta tahun ajaran 2015/2016”.Skripsi. Diakses online di: www.eprints.ums.ac.id.com . (diakses di Rejang Lebong, Indonesia: 2 September 2016)

Rahmawati, Zulaikha.2011. "Peningkatan Hasil Belajar IPA Tentang Gaya Dan Gerak Melalui Penerapan Model Pembelajaran Toys dan trick siswa kelas V SDN 01 Waleng Kecamatan Gerimarto Kabupaten Wonogiri Tahun pelajaran 2010 /2011”. Skripsi. Tersedia online di: www.eprints.ums.ac.id (diakses di Rejang Lebong, Indonesia:17 Januari 2016)

Sudjana.1990."Penilaian Hasil proses Belajar Mengajar"diakses onine di: www.fitriandianieikanrog.wordpres.com 
(diakses di rejang Lebong, Indonesia: 15 Januari 2016 )

Sukowati, Kanti.2014. "Meningkatkan Hasil Belajar Mata pelajaran IPA Materi gaya Dan gerak menggunakan Metode Demonstrasi Pada Siswa Kelas VI a SDN Darungan 01 Kecamatan Tanggul kabupaten Jember". Diakses online di: www.unej.ac.id/indek php/pancaran.com (diakses di Rejang Lebong, Indonesia: 5 Desember 2015)

Kemmis,S \& Taggart.(1988)."The Action Reasearch Planer,Victoria:Deakin University. 